\title{
WORK-RELATED RESPIRATORY SYMPTOMS AMONG HEALTH CENTRES CLEANERS: A CROSS-SECTIONAL STUDY
}

\author{
AGNIESZKA LIPIŃSKA-OJRZANOWSKA ${ }^{1}$, MARTA WISZNIEWSKA ${ }^{1}$, \\ DOMINIKA ŚWIERCZYŃSKA-MACHURA², TOMASZ WITTCZAK ${ }^{1}$, EWA NOWAKOWSKA-ŚWIRTA², \\ CEZARY PAŁCZYŃSKI ${ }^{1,2}$, and JOLANTA WALUSIAK-SKORUPA ${ }^{1}$
}

${ }^{1}$ Nofer Institute of Occupational Medicine, Łódź, Poland

Department of Occupational Diseases and Toxicology

${ }^{2}$ Nofer Institute of Occupational Medicine, Łódź, Poland

Department of Occupational Allergy and Environmental Health

\begin{abstract}
Objectives: Several studies, mostly based on questionnaire-derived data, have shown an increased risk of allergic diseases, especially asthma, among cleaners. The risk factors and etiological mechanisms are still being investigated. Occupational exposure to various chemical and biological agents may induce specific sensitization and/or irritant effects. The aim of our study was to estimate the prevalence of work-related symptoms suggesting the presence of allergic disease reported by cleaners, and to relate them to the results of commercially available and standardized objective tests used for screening detection of occupational sensitization and chronic respiratory disorders. Material and Methods: A cross-sectional study was performed among 142 Polish workers of cleaning service in their workplaces. A detailed questionnaire, skin prick tests to common allergens and chemicals used by these workers for cleaning purposes (chloramine T, chlorhexidine, formaldehyde, glutaraldehyde, benzalconium chloride), total and specific serum IgE antibodies to disinfectants and rest spirometry were performed in all the subjects. Results: Fifty nine percent of all the subjects declared occurrence of at least 1 symptom suggesting allergic ailment during cleaning activities at work. Skin prick tests and specific serum IgE antibodies to disinfectants were negative in all the subjects. In 8 cases wheezing was detected during auscultation, but only in 5 of them obstructive pattern in rest spirometry was found. Conclusions: Occupational allergic causation of symptoms among cleaners could be less likely than work-related symptoms associated with exacerbations of new-onset or pre-existing respiratory diseases. Therefore, in this group of workers, mainly the non-specific irritant impact of chemicals on airways should be taken into consideration.
\end{abstract}

Key words:

Cleaners, Occupational allergy, Work-related respiratory symptoms, Work-related asthma, WRA

\section{INTRODUCTION}

Cleaning job is one of the most dynamically developing areas of working services in Europe and cleaners constitute up to $10 \%$ of all working population [1,2]. This group of workers is exposed to a number of various agents in the workplace, including: chemicals, rubber gloves latex, fungal spores and house dust mites [2]. Due to their wide distribution, also in private households, daily exposure can be much stronger. The irritating effect of chemicals is well known, but their role in development of allergic inflammation is

Received: February 2, 2013. Accepted: February 14, 2014.

Corresponding author: A. Lipińska-Ojrzanowska, Department of Occupational Diseases and Toxicology, Nofer Institute of Occupational Medicine, św. Teresy 8 , 91-348 Łódź, Poland (e-mail: lipinska@imp.lodz.pl). 
still unclear. The results of the so far conducted research indicate a higher risk of allergic respiratory diseases among cleaners, especially of the new-onset occupational asthma and exacerbations of pre-existing asthma [3,4].

The aim of our study was to estimate the prevalence of symptoms suggesting the presence of work-related respiratory disease reported by Polish cleaners of health centres, and to relate them to the results of commercially available and standardized objective tests used for screening detection of occupational sensitization and chronic respiratory disorders.

\section{MATERIAL AND METHODS}

The study group included 142 cleaners, aged 23-62 years (age, mean \pm standard deviation: 46.2 \pm 1.4 ) and working in professional medical centres for an average 6.3 years, who were examined in their workplaces.

The participants underwent a detailed questionnaire [5] focused on past medical history and actual symptoms related to work (cough, dyspnoea, wheezing, rhinoconjunctivatis and skin disorders including pruritus), physical examination, rest spirometry and skin prick tests (SPT) to common allergens (tree and grass pollens, weeds, Dermatophagoides pteronyssinus, Dermatophagoides farinae, moulds (Allergopharma, Germany) and feathers (Stallergenes, France)). Spirometry was carried out using spirometer MicroLab (MicroMedical, England) and the best out of the 3 measurements was recorded. The results were expressed as a percentage of predicted values set by ERS/ATS norms [6].

On the basis of data obtained from the employers, information from the workers and material safety data sheets of used cleaning products, we determined the main exposure chemical compounds (chloramine T, chlorhexidine, formaldehyde, glutaraldehyde, benzalconium chloride). Skin prick tests to chemicals were performed in increasing concentrations $(1: 100$ and in the case of negative result - approximately 1:10 and then 1:1). Control groups consisted of 10 non-atopic and 10 atopic persons. All SPT included positive $(10 \mathrm{mg} / \mathrm{ml}$ histamine hydrochloride, Stallergenes, France) and negative controls (phenylated glycerol-saline, Stallergenes, France). Skin prick tests were performed on the volar part of the forearm using commercial extracts and standardized disposable lancets (Allergopharma, Germany). The results were assessed after 15 min. Positive SPT result was defined as a wheal diameter $\geq 3 \mathrm{~mm}$ in comparison with the negative control. Moreover, serum total IgE level and specific $\operatorname{IgE}$ (sIgE) to mixed disinfectants (pax6: chloramine, formaldehyde, ethylene oxide, phthalic anhydride) were evaluated in all the subjects by using the fluoroenzymeimmunoassay method (ImmunoCap System, Phadia, Sweden). A cut off value for detection of specific $\mathrm{IgE}$ was $0.35 \mathrm{kU} / \mathrm{l}$.

The subjects had been avoiding steroids, antihistamines or antidepressants for at least 1 month before testing.

\section{Ethics}

The specification of the study was approved by The Bioethical Committee at Nofer Institute of Occupational Medicine in Łódź (Poland) (decision number 20/2011). The subjects were informed in a written form about the research procedure and methods to be applied. Participation in the study was voluntary and required a written informed consent. Personal data were coded.

\section{Statistics}

Statistical data and univariate analysis were performed using programme Statistica'98.

\section{RESULTS}

Women comprised $136(95.7 \%)$ of all the study participants. Family history of atopy was positive in the case of $53(37 \%)$ subjects. Seventy eight subjects (55\% of the study population) declared presence of a pet at home. Eighty two (57\%) 
Table 1. Symptoms reported by the cleaners and related to work

\begin{tabular}{|c|c|c|c|c|c|c|c|c|c|c|c|c|c|c|}
\hline \multirow{3}{*}{$\begin{array}{l}\text { Characteristic of } \\
\text { the symptom }\end{array}$} & \multicolumn{14}{|c|}{$\begin{array}{l}\text { Work-related symptoms in cleaners } \\
\qquad(\mathrm{N}=142)\end{array}$} \\
\hline & \multicolumn{2}{|c|}{$\begin{array}{c}\text { at least one } \\
\text { symptom of } \\
\text { allergic disease }\end{array}$} & \multicolumn{2}{|c|}{ rhinitis } & \multicolumn{2}{|c|}{ conjunctivitis } & \multicolumn{2}{|c|}{$\begin{array}{l}\text { skin } \\
\text { symptoms }\end{array}$} & \multicolumn{2}{|c|}{ dyspnoea } & \multicolumn{2}{|c|}{ cough } & \multicolumn{2}{|c|}{ wheezing } \\
\hline & $\mathrm{n}$ & $\%$ & $\mathrm{n}$ & $\%$ & $\mathrm{n}$ & $\%$ & $\mathrm{n}$ & $\%$ & $\mathrm{n}$ & $\%$ & $\mathrm{n}$ & $\%$ & $\mathrm{n}$ & $\%$ \\
\hline Respondents & 84 & 59.0 & 49 & 34.5 & 38 & 26.8 & 34 & 24.0 & 36 & 25.4 & 34 & 24.0 & 30 & 21.1 \\
\hline $\begin{array}{l}\text { Symptom's onset after } \\
\text { beginning work as } \\
\text { a cleaner }\end{array}$ & 67 & 47.2 & 27 & 19.0 & 19 & 13.4 & 17 & 12.0 & 21 & 14.8 & 16 & 11.3 & 6 & 4.2 \\
\hline $\begin{array}{l}\text { Exacerbation during } \\
\text { work }\end{array}$ & 77 & 54.2 & 36 & 25.4 & 22 & 15.5 & 18 & 12.7 & 13 & 9.2 & 22 & 15.5 & 22 & 15.5 \\
\hline $\begin{array}{l}\text { Remission during break } \\
\text { from work }\end{array}$ & 69 & 48.6 & 26 & 18.3 & 19 & 13.4 & 19 & 13.4 & 12 & 8.5 & 9 & 6.3 & 16 & 11.3 \\
\hline
\end{tabular}

admitted to a smoking habit, among these 56 (39\%) were active smokers and 26 (18\%) were ex-smokers. 84 (59\%) participants reported at least 1 work-related symptom suggesting allergic disease. None of the study participants had had asthma, rhinoconjunctivitis or allergic skin disease recognised by a physician in the past. 67 (47.2\%) subjects developed at least 1 respiratory symptom during cleaning work. In general, airways ailments were observed most frequently - $64(45 \%)$, then ocular - $38(26,8 \%)$ and skin symptoms - $34(24 \%)$. Nasal symptoms were the most

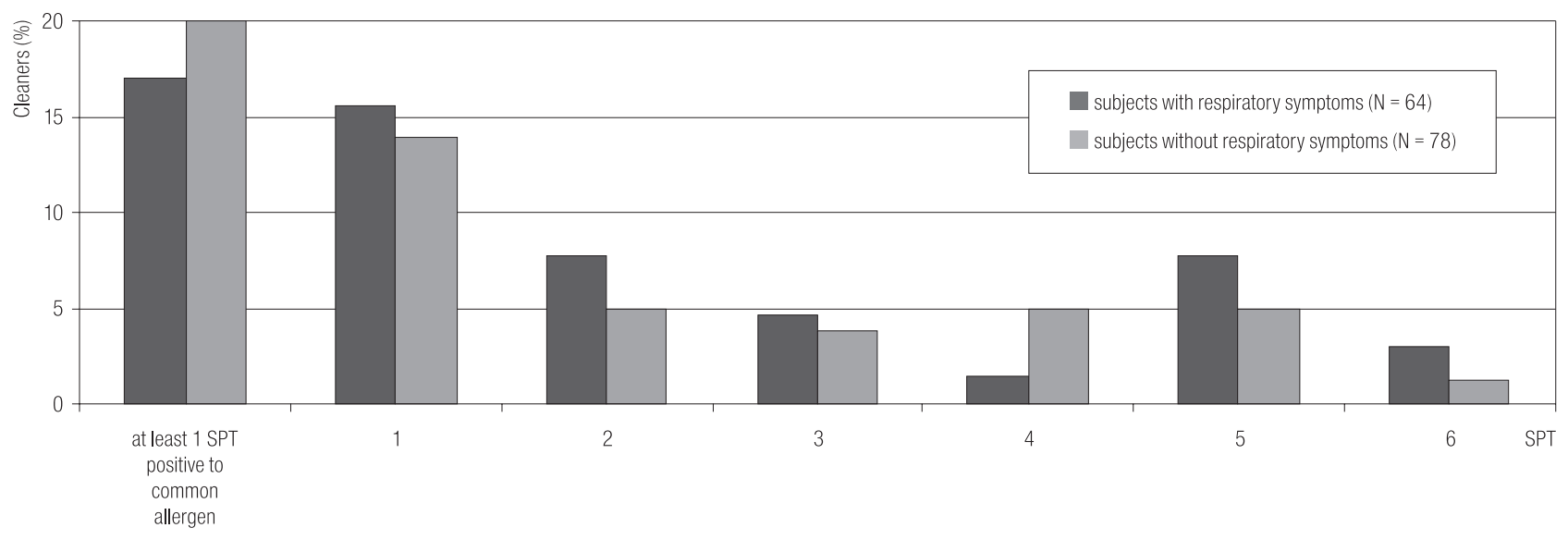

1 - house dust mites - Dermatophagoides farinae, Dermatophagoides pteronyssinus.

2 - mixed weeds - Taraxacum vulgare, Artemisia vulgaris, Plantago, Urtica dioica.

3 - mixed pollens - Dactylis glomerata, Festuca elatior, Phleum pratense, Holcus lanatus, Poa pratensis, Arrhenatherum sp.

4 - mixed moulds - Alternaria tenuis, Botrytis cinerea, Cladosporium herbarum, Culvularia lunata, Heliminthosporium, Fusarium moniliforme, Aspergillus fumigatus, Mucor mucedo, Penicillium notatum, Pullularia pullulans, Rhizopus nigricans, Serpula lacrimans.

5 - mixed trees - alder-tree, hazel, poplar, elm-tree, willow, birch, beech, oak, plane tree.

6 - mixed feathers - hen, goose, duck.

Fig. 1. Skin prick tests (SPT) results among the cleaners 
common ones, followed by conjunctivitis, skin symptoms and dyspnoea, cough and finally wheezing (Table 1).

Respiratory disorders in physical examination, such as impairment of nose patency or wheezing during auscultation, were found in 8 subjects (5.6\%). The mean baseline spirometric values in the study group did not show significant differences with reference to the predictive values. Only in 5 cases $(3.5 \%)$ obstructive changes in rest spirometry, according to the values set by the ERS/ATS norms, were recognized. Positive SPT to at least 1 common allergen was reported in 27 subjects (19\%), among these in 11 persons with respiratory symptoms and 16 without airways ailments. Sensitization to house dust mites was the most common one in both groups (Figure 1). We did not report any positive SPT to disinfectants solutions. Total IgE level averaged $90.6 \pm 6.5 \mathrm{IU} / \mathrm{ml}$ and the level above $100 \mathrm{IU} / \mathrm{ml}$ was found in $23(16 \%)$ subjects. sIgE to mixed disinfectants was not detected in the study group.

Statistical data revealed an important relationship between respiratory and ocular symptoms as well as skin symptoms occurrence (Table 2). Association between other factors (smoking habit, family history of atopy, presence of pets at home, positive result of at least 1 SPT to common allergen, total IgE level > $100 \mathrm{IU} / \mathrm{ml}$ ) and complaints concerning airways function disturbances was not found.

\section{DISCUSSION AND CONCLUSIONS}

In the European Community Respiratory Health Survey among 29 occupational groups, cleaning occupation had the 4th highest odds ratio (OR) -1.97 (95\% CI: 1.33-2.92) for asthma [7]. This kind of work may increase the risk of allergic (induced by senisitizers) as well as non-allergic asthma (usually induced by irritants) [4]. The prevalence of work-related asthma symptoms (WRAS) was established for $3.3 \%$, whereas for work-exacerbated asthma (WEA) and occupational asthma (OA) for appropriately $1.1 \%$ and $0.8 \%$, respectively among healthcare professionals occupationally exposed to cleaning agents [8].

The presence of occupational and non-occupational, high-molecular-weight (HMW) and low-molecular-weight (LMW) allergens in the workplace can modify immune response. For example, chloramine $\mathrm{T}$ is a well-recognised agent that may induce IgE-mediated allergic response [9] and chlorhexidine, widely used in cleaning products, can cause both IgE-mediated and non-IgE-mediated allergic reactions [10-12]. Formaldehyde is a well-known disinfectant, which may combine with larger protein molecules to create a new antigenic agent and probably induce specific IgE antibody production. However, it can also cause airways inflammation through a nonspecific irritant

Table 2. Association between respiratory symptoms occurrence and other potential determinants of allergic diseases development among cleaners

\begin{tabular}{lcccc}
\hline \multicolumn{1}{c}{ Clinical feature } & $\begin{array}{c}\text { Cleaners with } \\
\text { respiratory symptoms } \\
(\mathrm{N}=64) \\
(\mathrm{n})\end{array}$ & $\begin{array}{c}\text { Cleaners without } \\
\text { respiratory symptoms } \\
(\mathrm{N}=78) \\
(\mathrm{n})\end{array}$ & OR (95\% CI) & $\mathrm{p}$ \\
\hline Smoking habit & 39 & 42 & $1.34(0.65-2.77)$ & 0.390 \\
Family history of atopy & 27 & 27 & $1.38(0.66-2.88)$ & 0.350 \\
Presence of pets at home & 40 & 37 & $1.42(0.89-3.84)$ & 0.070 \\
At least 1 positive SPT to common allergen & 12 & 15 & $0.97(0.38-2.43)$ & 0.940 \\
IgE level (total) $>$ 100 IU/ml & 12 & 11 & $1.41(0.53-3.76)$ & 0.450 \\
Skin symptoms & 22 & 13 & $2.62(1.11-6.21)$ & 0.014 \\
Conjunctivitis & 29 & 9 & $6.35(2.53-16.34)$ & $<0.005$ \\
\hline
\end{tabular}

SPT - skin prick test; IgE - immunoglobulin E; OR - odds ratio; CI - confidence interval. 
effect [13]. What is more, some cleaning chemicals, like surfactants, may play a role of adjuvants which facilitate or intensify potential sensitization [14,15]. In our study a high prevalence of self-reported symptoms suggesting allergic disease in cleaners was not confirmed by the commercially available and standardized objective tests used for detection of occupational sensitization and pulmonary function disturbances. The presence of allergic symptoms in these workers may be elicited or deteriorated in the workplace by occurring in it irritants and non-occupational HMWallergens like dust mites.

The high rate of respiratory complaints among cleaners could also result from the high female proportion in this working group. Gender is considered as a risk factor for occurrence of respiratory symptoms during cleaning activities. Obadia et al. [16], according to questionnaire-derived data, have revealed a higher prevalence of respiratory complaints in women in comparison with men working in cleaning services. Gender differences may explain greater airways susceptibility to non-specific stimuli (non allergic) in women than in men. The mechanisms are related to different geometry of airways, significant cholinergic irritability and many hormonal factors [17]. However, this hypothesis needs further investigations, as our study did not comprise enough male participants to make any comparisons in relation to gender as a risk factor for developing allergic symptoms during cleaning.

Atopy among cleaners, defined as at least 1 positive SPT to common aeroallergens, was observed in $32.5 \%$ of 43 female subjects examined in a cross-sectional Macedonian study. Similarly to our study, in that group mite sensitization was the most important finding (20.9\%) [18]. There is little evidence to support the major role of atopy in respiratory symptoms reported by cleaners. Positive correlation between atopy and allergic rhinitis or asthma development has been revealed in a Brazilian study [19], but Zock et al. [19,20] have certified less frequent presence of atopy in cleaners with respiratory disorders than in different groups of workers.

Smoking habit was considered a risk factor for bronchial hypersensitivity among female cleaners and cooks [18]. Although positive correlation between these 2 points was observed in comparison to female office workers, it was not statistically important.

It seems that also the form of a cleaning product comes into prominence in developing allergy-like respiratory symptoms. The incidence of asthma is higher among cleaners who often use sprays [21]. Despite similar components of cleaning products, this trend was not observed among cleaners who usually used liquid chemicals [22]. Researchers suggested that using liquid forms of cleaning chemicals is connected with minor occurrence of asthma-like symptoms due to dust molecules hydration and decreased risk of inhaling them through the airways [23].

Chronic exposure as well as recurrent acute exposure to cleaning products seem to be risk factors for chronic respiratory disorders [24,25]. In a Brazilian study [26] the estimated risk of occupational allergic rhinitis and asthma development increased along with the period of employment as a professional cleaning worker. This fact imposes adequate monitoring of workers' health condition during examinations performed by prophylactic care physicians. Early recognition enables exposed workers to become aware of the necessity to avoid allergen and to begin treatment, which are ones of the most important factors preventing occupational disability.

Developing such a great number of potential allergic symptoms may result from non-IgE-mediated sensitization or irritant-induced mechanism. For this reason, certain extent of prevention should be related to educating workers and to devising safe methods during multi-use cleaning, both in occupational settings as well as in private households (avoiding mixing chemicals and using sprays, improving rooms ventilation during cleaning activities, using personal self-care equipment). 


\section{REFERENCES}

1. European Agency for Safety and Health at Work. The occupational safety and health of cleaning workers. Luxembourg: EU-OSHA; 2009, http://dx.doi.org/10.2802/21855.

2. Zock J. World at work: cleaners. Multiple occupational hazards in a large service sector. Occup Environ Med. 2005;62:581-4, http://dx.doi.org/10.1136/oem.2004.015032.

3. Jaakkola J, Jaakkola M. Professional cleaning and asthma. Curr Opin Allergy Clin Immunol. 2006;6(2):85-90, http:// dx.doi.org/10.1097/01.all.0000216849.64828.55.

4. Rosenman K, Reilly M, Schill D, Valiante D, Flattery J, Harrison $\mathrm{R}$, et al. Cleaning products and work-related asthma. JOEM. 2003;45(5):556-63.

5. Quirce S, Barranco P. Cleaning agents and asthma. J Investig Allergol Clin Immunol. 2010;20(7):542-50.

6. Pellegrino R, Viegi G, Brusasco V, Carpo R, Burgos F, Casaburi R, et al. Interpretative strategies for lung function tests. Eur Respir J. 2005;26:948-68, http://dx.doi.org/10.1183/0903 1936.05.00035205.

7. Kogevinas M, Antó J, Sunyer J, Tobias A, Kromhout H, Burney P. Occupational asthma in Europe and other industrialised areas: A population-based study. European Community Respiratory Health Survey Study Group. Lancet. 1999;353(9166):1750-4.

8. Arif A, Delclos G. Association between cleaning-related chemicals and work-related asthma and asthma symptoms among healthcare professionals. Occup Environ Med. 2012;69(1):35-40, http://dx.doi.org/10.1136/ oem.2011.064865.

9. Kramps J, van Toorrenenbergen A, Vooren P, Dijkman J. Occupational asthma due to inhalation of chloramine $\mathrm{T}$. II. Demonstration of specific IgE-antibodies. Int Arch Allergy Appl Immunol. 1981;64(4):428-38, http://dx.doi. org/10.1159/000232723.

10. Pham N, Weiner J, Reisner, G, Baldo B. Anaphylaxis to chlorhexidine. Case report. Implication of immunoglobulin $\mathrm{E}$ antibodies and identification of an allergenic determinant. Clin Exp Allergy. 2000;30(7):1001-7, http:// dx.doi.org/10.1046/j.1365-2222.2000.00887.x.

11. Layton G, Stanworth D, Amos H. The incidence of IgE and IgG antibodies to chlorhexidine. Clin Exp Allergy. 1989;19(3): 307-14, http://dx.doi.org/10.1111/j.1365-2222.1989.tb02388.x.

12. Garvey L, Kroigaard M, Poulsen L, Skov P, Mosbech H, Malling $\mathrm{H}$, et al. IgE-mediated allergy to chlorhexidine in twelve skin test positive patients - diagnosis verified by specific IgE measurement and histamine release. Data presented at the XXV Congress of the European Academy of Allergology and Clinical Immunology, June 2006 [not published].

13. McGwin G, Lienert J, Kennedy J. Formaldehyde exposure and asthma in children: A systematic review. Cienc Saude Coletiva. 2012;17(3):809, http://dx.doi.org/10.1590/S141381232012000300029.

14. Zock J, Kogevinas M, Sunyer J, Almar E, Muniozguren N, Payo F, et al. Asthma risk, cleaning activities and use of specific cleaning products among Spanish indoor cleaners. Scand J Work Environ Health. 2001;27:76-81, http://dx.doi. org/10.5271/sjweh.590.

15. Clausen S, Sobhani S, Poulsen O, Poulsen L, Nielsen G. Study of adjuvant effect of model surfactants from the groups of alkyl sulfates, alkylbenzene sulfonates, alcohol ethoxylates and soaps. Food Chem Toxicol. 2000;38:1065-74, http://dx.doi.org/10.1016/S0278-6915(00)00092-2.

16. Obadia M, Liss G, Lou W, Purdham J, Tarlo S. Relationships between asthma and work exposures among non-domestic cleaners in Ontario. Am J Ind Med. 2009;52(9):716-23, http://dx.doi.org/10.1002/ajim.20730.

17. Paoletti P, Carrozzi L, Viegi G, Modena P, Ballerin L, Di Pede F, et al. Distribution of bronchial responsiveness in a general population: Effect on sex, age, smoking, and level pulmonary function. Am J Respir Crit Care Med. 1995;151:1770-9, http://dx.doi.org/10.1164/ajrccm.151.6.7767519.

18. Karadzinska-Bislimovska J, Minov J, Risteska-Kuc S, Stoleski S, Mijakoski D. Bronchial hyperresponsiveness in women 
cooks and cleaners. Arh Hig Rada Toksikol. 2007;58(2): 223-31, http://dx.doi.org/10.2478/v10004-007-0017-3.

19. Zock J, Kogevinas M, Surtyer J, Anto J, Burney P. Respiratory health in cleaning and office workers with asthma: Suggestion of irritant induced asthma in cleaners. Eur Respir J. 2000;16 Suppl 31:520.

20. Zock J, Kogevinas M, Jarvis D, Toren K. Asthma characteristics in cleaning workers, workers in other risk jobs and office workers. Eur Respir J. 2002;20:679-85, http://dx.doi. org/10.1183/09031936.02.00279702.

21. Zock J, Plana E, Jarvis D, Anto J, Kromhout H, Kennedy S, et al. The use of household cleaning sprays and adult asthma: An international longitudinal study. Am J Respir Crit Care Med. 2007;176:735-41, http://dx.doi.org/10.1164/ rccm.200612-17930C.

22. Wolkoff P, Schneider T, Kildeso J, Degerth R, Jaroszewski M, Schunk H. Risk in cleaning: Chemical and physical exposure. Sci Total Environ. 1998;215:135-56, http://dx.doi. org/10.1016/S0048-9697(98)00110-7.
23. Medina-Ramon M, Zock J, Kogevinas M, Sunyer J, Torralba Y, Borrel A, et al. Asthma, chronic bronchitis and exposure to irritant agents in occupational domestic cleaning: A nested case-control study. Occup Environ Med. 2005;62:598-606, http://dx.doi.org/10.1136/ oem.2004.017640.

24. Balames J. Occupational airways diseases from chronic-level exposures to irritants. Clin Chest Med. 2002;23:727-35, http://dx.doi.org/10.1016/S0272-5231(02)00031-X.

25. Kogevinas M, Zock J, Jarvis D, Kromhout H, Lillienberg L, Plana E, et al. Exposure to substances in the workplace and new-onset asthma: An international prospective populationbased study (ECRHS II). Lancet. 2007;370:336-41, http:// dx.doi.org/10.1016/S0140-6736(07)61164-7.

26. De Fátima Maçãira E, Algranti E, Medina Coeli Mendonça E, Bussacos MA. Rhinitis and asthma symptoms in nondomestic cleaners from the Sao Paulo metropolitan area. Brasil Occup Environ Med. 2007;64(7):446-53, http://dx.doi. org/10.1136/oem.2006.032094.

This work is available in Open Access model and licensed under a Creative Commons Attribution-NonCommercial 3.0 Poland License - http://creativecommons.org/ licenses/by-nc/3.0/pl/deed.en. 